\title{
Deciphering evolution of polymetamorphic terranes: The Western Carpathians case study
}

\author{
D. PlaŠIENKA*, Š. MÉRES AND T. POTOČNÝ
}

Comenius University, 84215 Bratislava, Slovakia

(*correspondence: dusan.plasienka@uniba.sk)

The southern Western Carpathian zones of Slovakia include three large-scale tectonic units that exhibit complex structural and metamorphic relationships attained during several regional tectono-metamorphic phases. The lowermost Veporic thick-skinned thrust sheet is composed of high-grade pre-Alpine basement and Permian-Mesozoic cover overthrust by the Gemeric low-grade Paleozoic rocks. The overriding Meliatic Bôrka Nappe is composed of Permian to Jurassic complexes of Neo-Tethyan provenance affected by the Late Jurassic blueschist-facies metamorphism and overprinted by the Cretaceous greenschist-facies retrogression $[1,2]$.

Our EMPA monazite data from the Veporic and Meliatic rocks indicate three distinct age groups. The skarnoid body within the Veporic Variscan granitoids encloses older monazites $(359 \pm 4.2 \mathrm{Ma})$ as inclusions in garnets. The younger monazites with a dendritic habitus occur out of the garnets, most commonly in biotite or quartz. This younger monazite generation has the Late Cretaceous age 92 $\pm 7.2 \mathrm{Ma}$.

Sericite-chlorite phyllites of the Bôrka Nappe provided also two monazite age groups: older $(139 \pm 13 \mathrm{Ma})$ occur in the coarser-grained domains and younger $(97 \pm 5 \mathrm{Ma})$ are aligned parallel to a very fine-grained shear foliation. Similar phyllites from another locality contain post-kinematic oscillatory zoned monazite porphyroblasts. EMPA dating provided again two age groups: $147 \pm 17 \mathrm{Ma}$ and $89 \pm 18 \mathrm{Ma}$.

Accordingly, three tectono-metamorphic events can be discerned: (1) the oldest monazites indicate the Variscan event connected with intrusion of Variscan granitoids; (2) the 145-140 Ma age group from phyllites of the Bôrka Nappe indicates exhumation related to thrusting of the Meliatic accretionary wedge over the lower-plate Veporic and Gemeric units, following subduction of the Meliata Ocean; (3) the youngest monazite age group ranging 97-89 Ma from all analysed rocks records the Alpine retrograde overprint of the Veporic basement concurrently with recrystallization of the Meliatic complexes during the main phase of the Western Carpathian nappe stacking and commencing extension-related exhumation of the Veporic metamorphic dome [2, 3].

Acknowledgements: We appreciate financial aid from the Grant Agency for Science, Slovakia (VEGA 1/0085/17).

[1] Faryad \& Henjes-Kunst (1997) Tectonophysics 280, 141156. [2] Plašienka et al. (2019) Swiss J Geosci 112, 55-81. [3] Janák et al. (2001) J Metamorph Geol 19, 197-216. 